\title{
Melatonin enhances the apoptotic effects and modulates the changes in gene expression induced by docetaxel in MCF-7 human breast cancer cells
}

\author{
CAROLINA ALONSO-GONZÁLEZ* , JAVIER MENÉNDEZ-MENÉNDEZ* , ALICIA GONZÁLEZ-GONZÁLEZ, \\ ALICIA GONZÁLEZ, SAMUEL COS and CARLOS MARTÍNEZ-CAMPA
}

Department of Physiology and Pharmacology, School of Medicine, University of Cantabria and Valdecilla Research Institute (IDIVAL), ES-39011 Santander, Spain

Received August 29, 2017; Accepted November 15, 2017

DOI: $10.3892 /$ ijo.2017.4213

\begin{abstract}
Results from clinical trials and multiple in vivo and in vitro studies point to melatonin as a promising adjuvant molecule with many beneficial effects when concomitantly administered with chemotherapy. Melatonin palliates side-effects and enhances the efficacy of chemotherapeutic agents. However, the mechanisms through which melatonin regulates molecular changes induced by chemotherapeutic agents remain largely unknown. In this study, we demonstrated that melatonin enhanced the anti-proliferative and apoptotic responses to low doses of docetaxel in breast cancer cells. Importantly, these effects were more potent when melatonin was added prior to docetaxel. Treatment with $1 \mu \mathrm{M}$ docetaxel (equivalent to the therapeutic dosage) induced changes in gene expression profiles and melatonin modulated these changes. Specifically, docetaxel downregulated TP53, cyclin-dependent kinase inhibitor 1A (CDKN1A) and cadherin 13 (CDH13), and upregulated mucin 1 (MUCl), GATA binding protein 3 (GATA3) and $c-M Y C$, whereas melatonin counteracted these effects. Melatonin further stimulated the expression of the pro-apoptotic $B A D$ and $B A X$ genes, and enhanced the inhibition of the anti-apoptotic gene $B C L-2$ induced by docetaxel. The findings of this study suggest that melatonin is a molecule with potential for use as an adjuvant in cancer chemotherapy, which may have implications for designing clinical trials using chemotherapeutic drugs in combination with melatonin.
\end{abstract}

Correspondence to: Dr Carlos Martínez-Campa, Department of Physiology and Pharmacology, School of Medicine, University of Cantabria, Cardenal Herrera Oria s/n, ES-39011 Santander, Spain E-mail:martinezcm@unican.es

*Contributed equally

Key words: melatonin, breast cancer, docetaxel, chemotherapy, MCF-7 cells, gene expression, cell cycle, transcription factors, apoptosis

\section{Introduction}

Melatonin, mainly synthesized and secreted by the pineal gland, is known for its oncostatic actions on estrogen-dependent mammary tumors. Studies using both breast cancer animal models and breast cancer cell lines have examined the effects of nocturnal physiological concentrations of melatonin (1 nM), concluding that the pineal hormone, at this concentration, impairs the growth of estrogen-responsive breast cancer cell lines stimulated with estradiol through at least two different mechanisms: i) the downregulation of the neuroendocrine axis (therefore resulting in a reduction in estrogen levels); and ii) direct effects on tumoral and peritumoral cells. At this level, melatonin regulates the expression and activity of several enzymes necessary for the local synthesis of estradiol, thus behaving as a selective estrogen enzyme modulator (SEEM) (1-3). Additionally, the pineal hormone interferes directly with the effects of estrogens after their binding with the estrogen receptor (ER), therefore behaving as a selective estrogen receptor modulator (SERM). Melatonin impairs the transcriptional activation triggered by the $\mathrm{E}_{2}$-ER $\alpha$-calmodulin complex through destabilization of its binding at both EREand AP1 containing promoters (4). Of note, melatonin does not alter the recruitment of activators induced by the $E_{2}-E R \alpha$ complex, indicating that its actions differ from those of other anti-estrogens used in cancer therapy $(5,6)$. Several findings point to cyclic adenosine monophosphate (cAMP) as the likely link between the melatonin and estradiol pathways. In mammary tumor cells, estrogens activate adenylate cyclase, increasing cAMP levels; the increase in cAMP synergizes with the genomic actions of estradiol, promoting transcription (7). On the contrary, melatonin acting through its membrane receptor, MT1, decreases cAMP levels (8). As a result, this indoleamine reduces the expression of estrogen-regulated proteins, growth factors and proto-oncogenes [transforming growth factor $(T G F) \alpha, c-M Y C, p S 2$, progesterone receptor (PGR), $c F O S$ and $T G F \beta$ ] in human breast cancer cells $(9,10)$.

Similar to the effects of tamoxifen, the treatment of human breast cancer cells with melatonin has been shown to cause a $G_{1}-S$ transition delay (11), probably through the differential expression of proteins controlling the $\mathrm{G}_{1}-\mathrm{S}$ transition. Thus, 
melatonin increases the expression of TP53 (12) and inhibits that of human telomerase reverse transcriptase (hTERT) $(13,14)$. Additionally, melatonin blocks the invasion of cells induced by estradiol (15), and importantly, melatonin exerts a modulatory effect in the tumor microenvironment, inhibiting the secretion of cytokines by breast cancer cells (16-18).

Several clinical trials have been performed to assess the value of melatonin as an adjuvant in human neoplasms and have revealed multiple beneficial effects of melatonin when used concomitantly with chemotherapeutic agents. Chemotherapy is better tolerated when administered to cancer patients in conjunction with melatonin. The pineal hormone protects from side-effects, such as asthenia, cardiotoxicity and neurotoxicity, and it increases both the 1- and 5-year survival rates and the objective tumor regression in patients with metastatic solid tumors (19-23).

Melatonin exerts anticancer effects at different phases of carcinogenesis, namely initiation, progression and spreading from the primary tumor (24). Recently, studies have addressed the potential benefits that melatonin could have on the effects of chemotherapeutic agents (25). The disruption of the nocturnal melatonin rhythm contributes to a complete loss of tumor sensitivity to doxorubicin (26), whereas melatonin co-treatment sensitizes cancer cells to this drug, increasing doxorubicin intracellular concentrations, possibly through a downregulation in the levels of P-glycoprotein (27). Melatonin induces Bim upregulation and cyclooxygenase (COX)-2 downregulation, thus enhancing the tunicamycin-induced apoptosis of breast cancer cells (28), and sensitizing non-small-cell lung cancer cells harbouring an epidermal growth factor receptor $(E G F R)$ mutation to gefitinib, a specific tyrosine kinase inhibitor (29). The pineal hormone enhances cisplatininduced cytotoxicity and the apoptosis of lung cancer and cervical cancer cells $(30,31)$. Additionally, co-treatment with melatonin and each of three different chemotherapeutic agents (5-fluorouracil, cisplatin and doxorubicin) has been shown to result in the enhanced chemotherapy-induced cytotoxicity and apoptosis of the rat pancreatic tumor cell line, AR42J (32). In ER-responsive mammary cancer rat models treated with adriamycin, melatonin co-treatment was shown to result in lighter tumor weights, increased apoptosis, a higher expression of E-cadherin and a higher survival rate (33). In MCF-7 cells, melatonin has been shown to exert synergistic effects with doxorubicin on apoptosis and the activation of transient receptor potential vanilloid (TRPV)1 channels (34). In prostate cancer cells, melatonin combined with doxorubicin, docetaxel or etoposide, has been shown to make cells more sensitive to these compounds (35). Finally, as regards its ability to modulate global gene expression, melatonin influences both microRNA (miRNA or miR) and gene expression. In a global gene expression study on MCF-7 cells, 22 miRNAs were found to be differentially expressed in melatonin-treated cells (36).

Thus, since melatonin: i) is associated with oncostatic actions both in vivo and in vitro; ii) sensitizes many cell lines to treatment with different chemotherapeutic agents; and iii) seems to exert several beneficial effects when administered concomitantly with chemotherapeutic agents to patients bearing solid tumors, in the present study we investigated the effects of melatonin on the proliferation, cell cycle progression and gene transcription in estrogen-sensitive MCF-7 human breast cancer cells treated with docetaxel, a microtubuleinterfering agent that stabilizes microtubules, commonly used in chemotherapy. Docetaxel belongs to the family of taxanes, a class of diterpenes used in the treatment of various types of cancer, including breast cancer.

\section{Materials and methods}

Cells and culture conditions. MCF-7 human breast cancer cells were purchased from the American Tissue Culture Collection (ATCC, Rockville, MD, USA). They were maintained as monolayer cultures in $75-\mathrm{cm}^{2}$ plastic culture flasks in Dulbecco's modified Eagle's medium (DMEM) (Sigma-Aldrich, Madrid, Spain) supplemented with $10 \%$ fetal bovine serum (FBS) (PAA Laboratories, Pasching, Austria), penicillin $(20 \mathrm{U} / \mathrm{ml})$ and streptomycin $(20 \mu \mathrm{g} / \mathrm{ml})$ (Sigma-Aldrich) at $37^{\circ} \mathrm{C}$ in a humid atmosphere containing $5 \% \mathrm{CO}_{2}$.

Cell proliferation assay. The cells were initially cultured for $24 \mathrm{~h}$ in DMEM supplemented with $0.5 \%$ dextran-charcoal stripped FBS (csFBS) prior to being seeded in 96-multi-well plates in DMEM supplemented with 10\% FBS and incubated at $37^{\circ} \mathrm{C}$ for $24 \mathrm{~h}$ to allow for cell attachment. Melatonin pre-treated cells were incubated for $24 \mathrm{~h}$ in DMEM supplemented with $10 \%$ FBS containing melatonin ( $1 \mathrm{nM})$. Following pre-treatment, both the melatonin-treated and the control cells were seeded into 96-multi-well plates at a density of $3 \times 10^{3}$ cells per well, and incubated at $37^{\circ} \mathrm{C}$ for $24 \mathrm{~h}$ to allow for cell attachment. The media were replaced with fresh media with $10 \%$ FBS containing docetaxel ranging from $1 \mu \mathrm{M}$ to $10 \mathrm{pM}$, plus/minus melatonin $(1 \mathrm{nM})$ and/or the vehicle (ethanol at a final concentration $<0.0001 \%$ ). The cells were cultured for 3 or 6 days and cell proliferation was measured by 3(4,5dimethylthiazol-2-yl)-2,5-diphenyl tetrazolium bromide (MTT) assay. Briefly, yellow MTT $(5 \mathrm{mg} / \mathrm{ml}$ in PBS) is reduced to purple formazan in the mitochondria of living cells. This reduction takes place only when mitochondrial reductase enzymes are active, and therefore conversion can be directly related to the number of viable cells. The formazan crystals can be dissolved by the addition of $4 \mathrm{mM} \mathrm{HCl}$. An increase in cell number is directly related to the increase in absorbance due to the amount of MTT formazan formed (37). After $24 \mathrm{~h}$, the absorbance is read at $570 \mathrm{~nm}$ on a microplate reader (Labsystems Multiskan RC 351; Thermo LabSystems Inc. Vienna, VA, USA). MTT solution was obtained from Molecular Probes Inc. (Eugene, OR, USA). Each result represents the median \pm standard error of the mean (SEM) of 3 independent experiments and data are presented as a percentage of the untreated control cells.

Measurement of cell cycle kinetics. The cells were initially cultured for $24 \mathrm{~h}$ in DMEM supplemented with $0.5 \%$ dextrancsFBS prior to being seeded in 96-multi-well plates in DMEM supplemented with $10 \% \mathrm{FBS}$ and incubated at $37^{\circ} \mathrm{C}$ for $24 \mathrm{~h}$ to allow for cell attachment. The control cells and cells pre-treated with melatonin $(1 \mathrm{nM})$ for $24 \mathrm{~h}$ were seeded in 6-well plates at a density of $5 \times 10^{5}$ cells per well, in DMEM supplemented with $10 \% \mathrm{FBS}$ and incubated at $37^{\circ} \mathrm{C}$ for $24 \mathrm{~h}$ to allow cell attachment. The media were then replaced with fresh media with $10 \%$ FBS containing either docetaxel alone $(1 \mathrm{nM})$ or in combination with melatonin $(1 \mathrm{nM})$ and/or the vehicle (ethanol 
at a final concentration $<0.0001 \%$ ). After $24 \mathrm{~h}$ of incubation, the cells were harvested with trypsin, washed twice with phosphate-buffered saline (PBS), and fixed in $70 \%$ cold ethanol for $30 \mathrm{~min}$. Following the removal of ethanol by centrifugation for $5 \mathrm{~min}$ at $300 \mathrm{x} \mathrm{g}$, the cells were stained with a solution containing $50 \mu \mathrm{g} / \mathrm{ml}$ propidium iodide (PI) (Sigma-Aldrich) and incubated in the dark for $30 \mathrm{~min}$ at room temperature. In total, 10,000 cells were acquired for each sample on a BD FACSCanto II analyzer (BD Biosciences, San Jose, CA, USA). The cell cycle distribution was determined using a DNA software program (FACSDiva software; BD Biosciences).

Determination of cell apoptosis. The induction of apoptosis was determined using an Annexin V-FITC apoptosis detection kit (Miltenyi Biotec GmbH, Germany), according to the manufacturer's instructions. Briefly, the control cells and cells pre-treated with melatonin $(1 \mathrm{nM})$ were seeded in 6-well plates at a density of $3 \times 10^{5}$ cells per well in DMEM supplemented with $10 \% \mathrm{FBS}$ and incubated at $37^{\circ} \mathrm{C}$ for $24 \mathrm{~h}$ to allow for cell attachment. The media were then replaced by fresh media containing docetaxel $(1 \mathrm{nM})$ plus/minus melatonin $(1 \mathrm{nM})$ and/or the vehicle (ethanol at a final concentration $<0.0001 \%$ ). After $24 \mathrm{~h}$ of incubation, the cells were harvested, washed twice with PBS, and centrifuged at $300 \mathrm{x}$ g for $10 \mathrm{~min}$; the cells were resuspended in $100 \mu \mathrm{l}$ binding buffer containing $5 \mu \mathrm{l}$ of Annexin V-FITC, incubated for $15 \mathrm{~min}$ at room temperature, washed twice, and finally resuspended in $500 \mu \mathrm{l}$ binding buffer containing $5 \mu \mathrm{l}$ of PI. Cells were immediately analyzed following incubation with the probes using a flow cytometer (BD FACSCanto II analyzer; BD Biosciences). A total of 10,000 events were analyzed using the FL-1 (green; Annexin V-FITC) and FL-3 (red; PI) detectors. Each sample was tested 3 times in independent experiments. Under all conditions tested, the percentages of Annexin $/ \mathrm{PI}^{-}$(alive) and Annexin ${ }^{+} / \mathrm{PI}^{-}$cells (early apoptotic) cells were compared.

RNA isolation and cDNA synthesis. Total RNA was isolated from the MCF-7 cells and purified using the Nucleospin RNA II kit (Macherey-Nagel GmbH \& Co,. Düren, Germany) following the manufacturer's instructions. The concentration and purity of the RNA was quantified by measuring the absorbance on a spectrophotometer (Nanodrop 1000; Thermo Fisher Scientific, Wilmington, DE, USA). The absorbance ratio A260 nm/A280 nm was always $>1.9$. For cDNA synthesis, $0.5 \mu \mathrm{g}$ of total RNA was used as template using the $\mathrm{RT}^{2}$ First Strand kit (Qiagen, Valencia, CA, USA), following the manufacturer's instructions. First, the genomic DNA was eliminated by incubating the samples $5 \mathrm{~min}$ at $42^{\circ} \mathrm{C}$. After mixing with the reverse transcription mix, the samples were incubated for exactly $15 \mathrm{~min}$ at $42^{\circ} \mathrm{C}$ in a final volume of $20 \mu \mathrm{l}$. The reaction was terminated by incubation at $95^{\circ} \mathrm{C}$ for $5 \mathrm{~min}$. Subsequently, $91 \mu \mathrm{l}$ of RNA-free water was added to each reaction and the samples were kept on ice until proceeding with the real-time PCR protocol.

$R T^{2}$ Profiler $^{\mathrm{TM}}$ PCR array. Pathway-focused gene expression profiling was performed using a 96-well human breast cancer PCR array (RT ${ }^{2}$ Profiler PCR array - PAHS-131ZA, Human Breast Cancer PCR array, Qiagen, Valencia, CA, USA). In this array, each well contains all the components required and designed to generate single, gene-specific amplicons, testing the expression of 84 genes related to breast cancer pathways (apoptosis, metabolism, cell cycle and DNA repair), plus 5 housekeeping genes. Each $\mathrm{RT}^{2}$ Profiler PCR array plate also includes controls for data normalization, genomic DNA contamination detection, RNA sample quality and general PCR performance.

Briefly, the MCF-7 cells were seeded in 6-well plates in DMEM supplemented with $10 \%$ FBS and incubated at $37^{\circ} \mathrm{C}$ for $24 \mathrm{~h}$ to allow for cell attachment. The media were then replaced with fresh media with $10 \%$ FBS and containing either docetaxel (Sigma-Aldrich) alone $(1 \mu \mathrm{M})$ or in combination with $1 \mathrm{nM}$ melatonin (Sigma-Aldrich) and/or the vehicle (ethanol at a final concentration $<0.0001 \%$ ). After $6 \mathrm{~h}$ of incubation, total RNA was extracted and reverse transcribed as explained in the 'RNA isolation and cDNA synthesis' section. The cDNA template was mixed with the appropriate amount of RT $^{2}$ SYBR-Green qPCR Mastermix (Qiagen $\mathrm{GmbH}$, Hilden, Germany), aliquoted $25 \mu \mathrm{l}$ to each well of the same plate, and then the real-time PCR cycling program was performed on an MX3005P (Agilent, CA, USA) following the manufacturer's instructions. Amplification was initiated by 1 cycle at $95^{\circ} \mathrm{C}$ for $10 \mathrm{~min}$ and then performed for 40 cycles for quantitative analysis using the following temperature profile: $95^{\circ} \mathrm{C}$ for $30 \mathrm{sec}$ (denaturation); $60^{\circ} \mathrm{C}$ for $60 \mathrm{sec}$ (annealing/ extension). Dissociation curves were performed to verify that only a single product was amplified. The $\mathrm{Ct}$ data for each gene were analyzed using the Qiagen $\mathrm{RT}^{2}$ profiler PCR array data analysis software. Data are represented as the fold-regulation between the experimental groups and the control cells. Fold change values $<1$ indicate a negative result or downregulation, and the fold -regulation is the negative inverse of the fold change.

Measurement of specific mRNA gene expression. The analysis of mRNA gene expression was carried out by RT-qPCR following incubation of the cells for $6 \mathrm{~h}$ with docetaxel $(1 \mu \mathrm{M}$ or $1 \mathrm{nM})$, in the presence or absence of melatonin $(1 \mathrm{nM})$. Total cellular RNA was isolated and reverse transcribed as indicated above and RT-PCR was performed on an Mx3005P QPCR System (Agilent Technologies, Santa Clara, CA, USA) using the same temperature profile. Reactions were run in triplicate and melting curves were performed to verify that only a single product was amplified. Each result represents the median of 3 to 5 independent experiments and data are presented as the fold change between the experimental groups and the control cells. The primers used for amplification (Sigma Genosys Ltd., Cambridge, UK) are listed in Table I.

Analysis of RT-qPCR data. For the primers used there were no differences between transcription efficiencies, and the fold change in each sample was calculated using the $2^{-\Delta \Delta \mathrm{Cq}}$ method (38). The fractional cycle at which the amount of amplified target becomes significant $(\mathrm{Ct})$ was automatically calculated by the PCR program. The relative expression of $\beta$-actin was used to normalize gene expression.

Statistical analysis. Statistical analyses were performed using GraphPad Prism software. The data are expressed as the means \pm SEM. Statistical differences between groups 
Table I. Primers used for the amplification of mRNA transcripts.

\begin{tabular}{ll}
\hline mRNA & \multicolumn{1}{c}{ Sequence } \\
\hline$\beta$-ACTIN FW & 5'-TCCTGCGAGTGCTGTCAGAG-3' \\
$\beta$-ACTIN RV & 5'-TCACCGCCTACACATCAAAC-3' \\
BAX FW & 5'-AACTGGACAGTAACATGGAG-3' \\
BAX RV & 5'-TTGCTGGCAAAGTAGAAAAG-3' \\
BAD FW & 5'-ATCATGGAGGCGCTG-3' \\
BAD RV & 5'-CTTAAAGGAGTCCACAAACTC-3' \\
BCL-2 FW & 5'-CCTTTGGAATGGAAGCTTAG-3' \\
BCL-2 RV & 5'-GAGGGAATGTTTTCTCCTTG-3' \\
CDKN1A & 5'-CAGCATGACAGATTTCTACC-3' \\
(p21) FW & \\
CDKN1A & 5'-CAGGGTATGTACATGAGGAG-3' \\
(P21) RV & \\
GATA3 FW & 5'-CGGTCCAGCACAGGCAGGGAGT-3 \\
GATA3 RV & 5'-GAGCCCACAGGCATTGCAGACA-3' \\
MYC FW & 5'-TGAGGAGGAACAAGAAGATG-3' \\
MYC RV & 5'-ATCCAGACTCTGACCTTTTG-3' \\
MUC1 FW & 5'-GCAAGAGCACTCCATTCTCAATT-3' \\
MUC1 RV & 5'-TGGCATCAGTCTTGGTGCTATG-3' \\
TP53 FW & 5'-CAGCCAAGTCTGTGACTTGCACGTAC-3' \\
TP53 RV & 5'-CTATGTCGAAAAGTGTTTCTGTCATC-3'
\end{tabular}

$\mathrm{FW}$, sense (forward) primer; RV, antisense (reverse) primer.

were analyzed using one-way analysis of variance (ANOVA), followed by the Student-Newman-Keuls test. Results were considered as statistically significant at $\mathrm{p}<0.05$. To confirm whether the effects of docetaxel and melatonin are synergistic as regards gene expression ( $B A D$ and $B C L-2$ expression) and apoptosis, linear regression models were obtained in order to estimate the independent effects of melatonin, docetaxel and their interaction.

\section{Results}

Effects of docetaxel and melatonin on cell proliferation and cytotoxicity. Our first goal was to determine whether melatonin potentiates the anti-proliferative effects of docetaxel in MCF-7 cells. As expected, docetaxel inhibited the proliferation of the MCF-7 cells in a dose-dependent manner. When the cells were treated with docetaxel at $1 \mu \mathrm{M}$, proliferation was decreased by almost $80 \%$ after 3 days, indicating that the majority of the cells were dead (Fig. 1A). For this reason, we examined the effect of physiological concentrations of melatonin $(1 \mathrm{nM})$ combined with low concentrations of docetaxel at $1 \mathrm{nM}$ and $0.1 \mathrm{nM}$.

Consistent with previous findings of our group (1), after 6 days of treatment, melatonin alone induced an inhibitory effect on the proliferation of MCF-7 cells (Fig. 1B). Docetaxel (0.1 nM) also had a slight, but significant inhibitory effect on cell proliferation (8\%), whereas docetaxel $(1 \mathrm{nM})$ treatment resulted in a $62 \%$ decrease in cell viability. Of note, co-treatment of the cells with docetaxel and a physiological concentration of melatonin
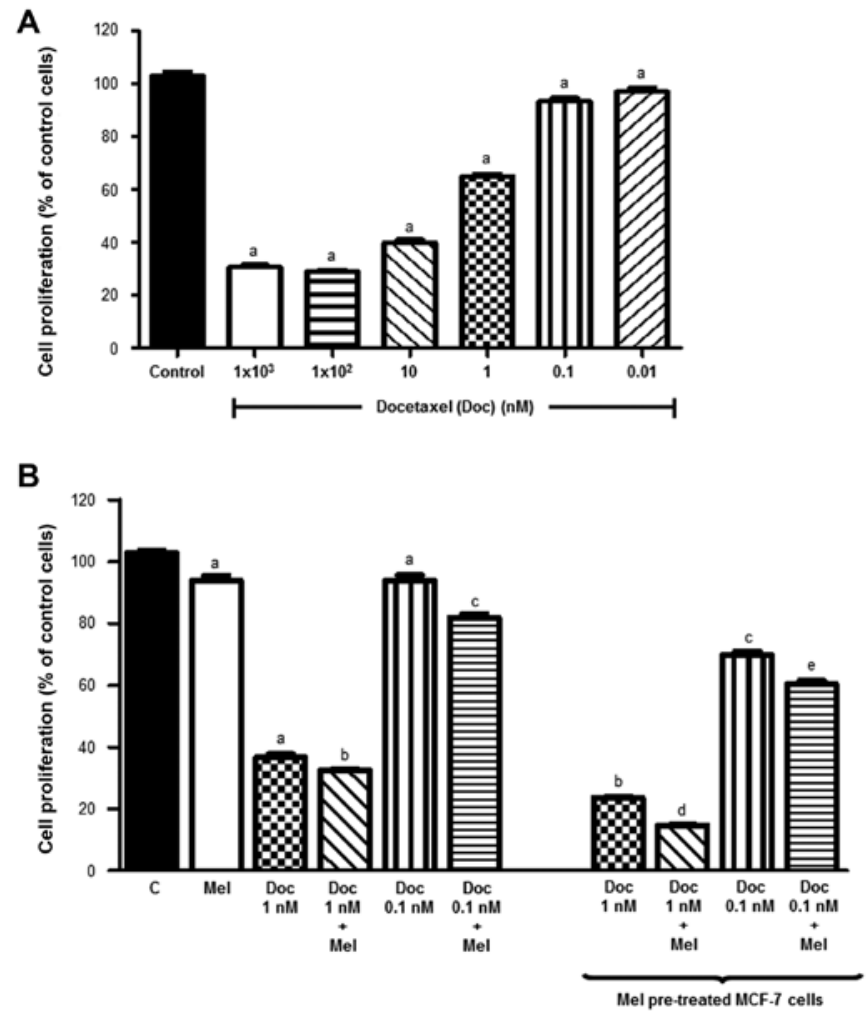

Figure 1. Effects of docetaxel and melatonin on MCF-7 cell proliferation. (A) Control (untreated) and docetaxel-treated (ranging from $1 \mu \mathrm{M}$ to $10 \mathrm{pM}$ ) MCF-7 cells were seeded in 96-multi-well plates in DMEM supplemented with $10 \% \mathrm{FBS}$ and incubated at $37^{\circ} \mathrm{C}$ for 3 days. Cell proliferation was then measured by MTT assay. (B) MCF-7 cells were seeded in 96-multi-well plates in DMEM supplemented with $10 \%$ FBS and docetaxel (1 nM or $0.1 \mathrm{nM})$ alone or in combination with melatonin $(1 \mathrm{nM})$. Melatonin pre-treated MCF-7 cells were seeded for $24 \mathrm{~h}$ in DMEM supplemented with $10 \%$ FBS containing melatonin $(1 \mathrm{nM})$ prior to docetaxel $(1 \mathrm{nM}$ or $0.1 \mathrm{nM})$ treatment. Cell proliferation was measured by MTT assay after 6 days of incubation. Data are expressed as the percentage of the control group (means \pm SEM) from 4 independent experiments; ${ }^{\mathrm{a}} \mathrm{p}<0.001 \mathrm{vs}$. control; ${ }^{\mathrm{b}} \mathrm{p}<0.001 \mathrm{vs}$. docetaxel $1 \mathrm{nM}$; ${ }^{\mathrm{c}} \mathrm{p}<0.001$ vs. docetaxel $0.1 \mathrm{nM}$. Doc, docetaxel; Mel, melatonin.

$(1 \mathrm{nM})$ significantly potentiated the inhibitory effects on cell proliferation induced at both docetaxel concentrations. When the cancer cells were pre-treated with melatonin for $24 \mathrm{~h}$, a significant further decrease in cell proliferation was obtained. For docetaxel $(1 \mathrm{nM})$, a $77 \%$ decrease in cell proliferation was obtained when the cells were pre-treated with melatonin (whereas for non pre-treated cells the decrease in cell proliferation observed was $62 \%)$. For docetaxel $(0.1 \mathrm{nM})$, a $27 \%$ decrease in cell proliferation was obtained when the cells were pre-treated with $1 \mathrm{nM}$ melatonin, (whereas an $8 \%$ decreased was obtained in the in non pre-treated cells). Moreover, significant differences were observed when melatonin was maintained in the medium following treatment with docetaxel, the effect of the indolamine being a further reduction in cell proliferation.

Effects of docetaxel and melatonin on cell cycle phase distribution. The effects of melatonin, docetaxel and co-treatment with both molecules on cell cycle phase distribution in the MCF-7 cells are shown in Fig. 2A, and the percentage of cells in the sub $G_{0}-G_{1}, G_{1}, S$, and $G_{2}-M$ phases is represented in Fig. 2B. As expected, treatment of the cells with melatonin $(1 \mathrm{nM})$ for $24 \mathrm{~h}$ induced an increase in the proportion of cells 
A
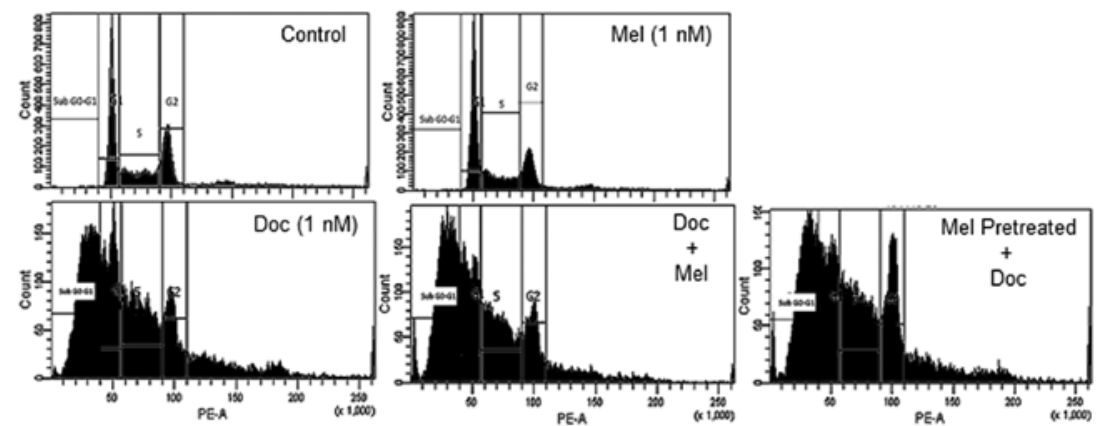

B
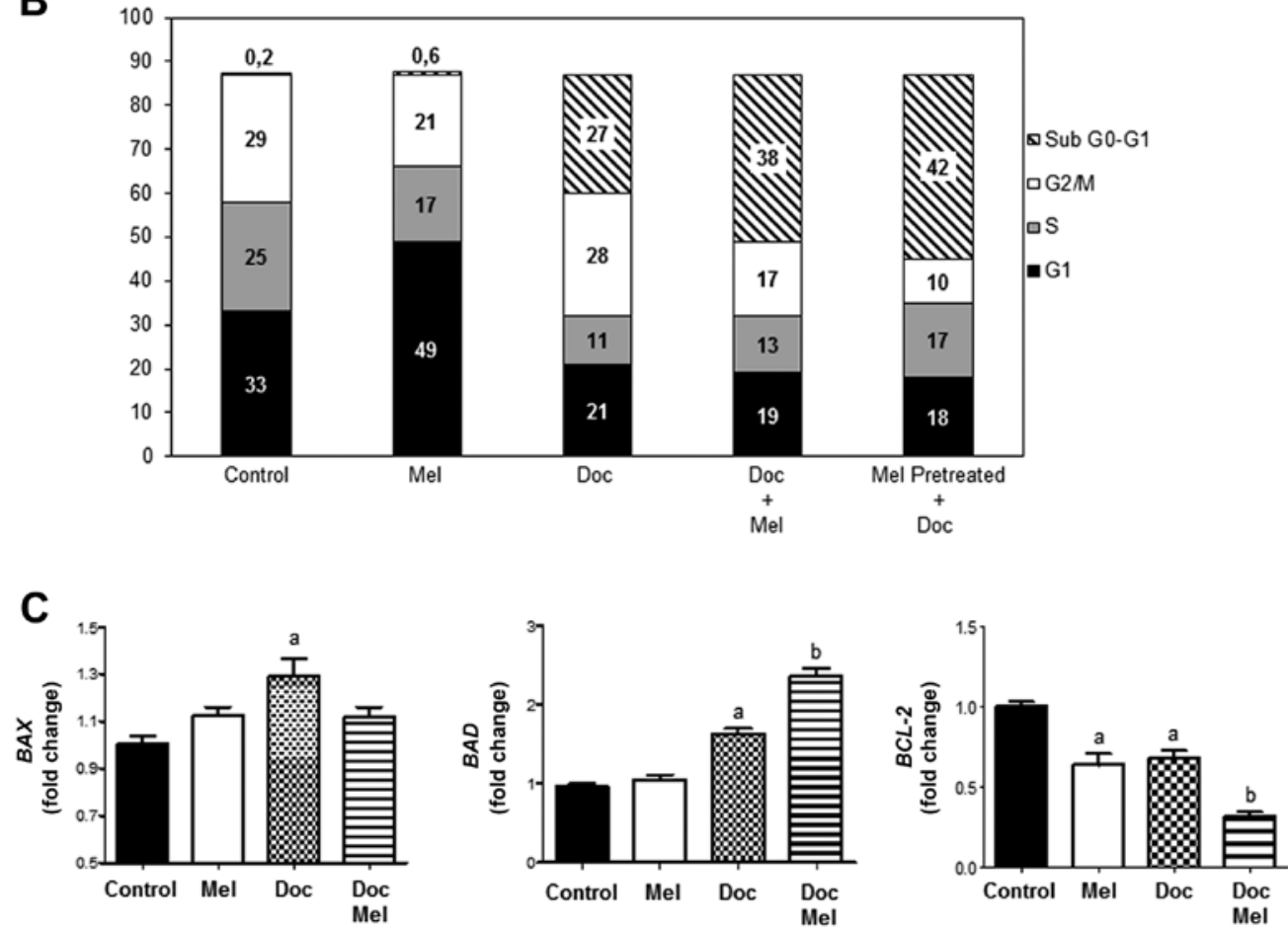

Figure 2. Effects of docetaxel and melatonin on cell cycle distribution and the expression of apoptosis-related genes in MCF-7 cells. Cells were seeded in 6-well plates in DMEM supplemented with 10\% FBS containing either docetaxel $(1 \mathrm{nM})$ alone or in combination with melatonin (1 nM). Melatonin pre-treatment consisted of incubation with melatonin $(1 \mathrm{nM})$ for $24 \mathrm{~h}$ prior to the addition of docetaxel. After $24 \mathrm{~h}$, the cells were harvested, stained with propidium iodide (PI) and analyzed by flow cytometry to determine the number of cells present in each phase of the cell cycle. (A) Histograms showing cell cycle distribution by flow cytometry. (B) Quantification of the number of cells present in each phase of the cell cycle, including the number of cells present in the sub- $\mathrm{G}_{0}-\mathrm{G}_{1}$ phase. (C) Effects of docetaxel $(1 \mathrm{nM})$ and melatonin $(1 \mathrm{nM})$ on the mRNA expression of pro-apoptotic BAX and BAD, and anti-apoptotic $B C L-2$. MCF-7 cells were incubated with docetaxel $(1 \mathrm{nM})$, melatonin $(1 \mathrm{nM})$ or both molecules for $6 \mathrm{~h}$, and total mRNA was then isolated from the cells and reverse transcribed. Data are expressed as a fold change relative to the control cells (means \pm SEM). All data are representative of 3 independent experiments; ${ }^{\mathrm{a}} \mathrm{p}<0.001$ vs. control; ${ }^{\mathrm{b}} \mathrm{p}<0.001$ vs. docetaxel. Doc, docetaxel; Mel, melatonin.

in the $\mathrm{G}_{1}$ phase, thus causing a delay in the transition to the $\mathrm{S}$ phase. As expected, a higher number of cells in the sub $\mathrm{G}_{0}-\mathrm{G}_{1}$ phase was evident when the cells were treated with docetaxel $(1 \mathrm{nM})$ for $24 \mathrm{~h}(27 \%)$. When the cells were treated with a combination of melatonin and the taxane, a significant increase in the number of cells in this phase was observed (38\%). Of note, treatment with melatonin for $24 \mathrm{~h}$ prior to the addition of docetaxel resulted in the highest percentage of cells in the sub $\mathrm{G}_{0}-\mathrm{G}_{1}$ phase (42\%), suggesting DNA fragmentation as a consequence of cell death (Fig. 2B).

We then wished to determine whether the results obtained by flow cytometric analysis correlated with the expression of genes involved in apoptosis. The mRNA expression of the pro-apoptotic genes, $B A D$ and $B A X$, was stimulated, whereas the mRNA levels of the anti-apoptotic $B C L-2$ gene were significantly decreased by docetaxel $(1 \mathrm{nM})$. When the cells were treated with both compounds, melatonin further enhanced the effects of the taxane on $B A D$ and $B C L-2$ expression. However, at this low concentration of docetaxel (together with melatonin), the pineal hormone had no significant effect on $B A X$ expression. Melatonin alone induced a moderate, yet significant downregulation in the levels of $B C L-2$ (Fig. 2C).

Effects of docetaxel and melatonin on cell apoptosis. To examine whether the anti-proliferative effects and the changes in the cell cycle phase distribution were related to the induction of apoptosis, we treated the MCF-7 cells with docetaxel $(1 \mathrm{nM})$, alone or in combination with $1 \mathrm{nM}$ melatonin for $24 \mathrm{~h}$ and used an Annexin V-FITC apoptosis detection kit, which enables the differentiation of viable cells from apoptotic and 
A
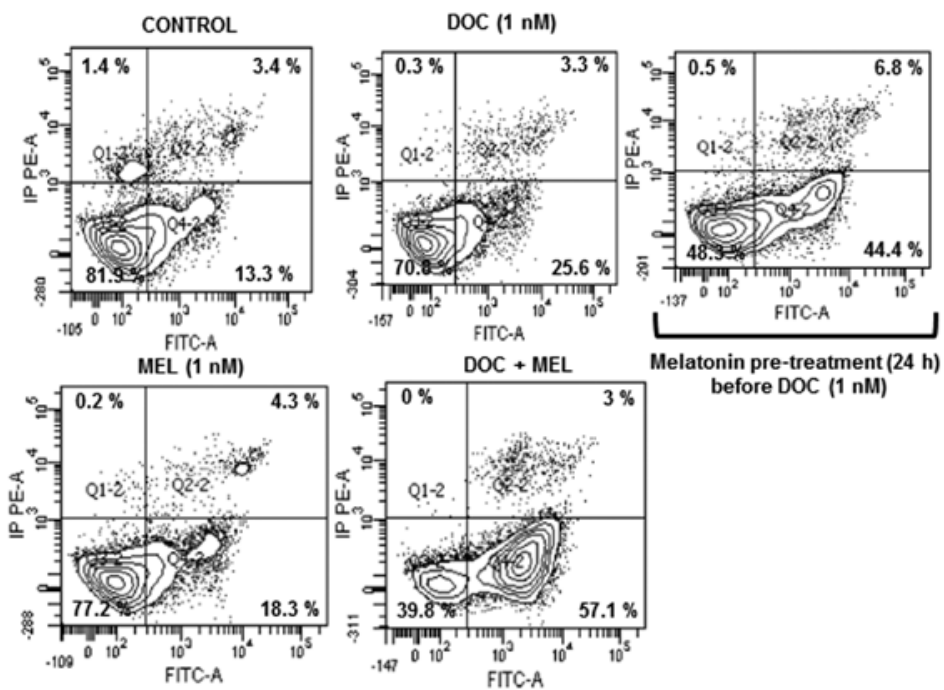

Melatonin pre-treatment $(24 \mathrm{~h})$ before DOC (1 $\mathrm{nM})$

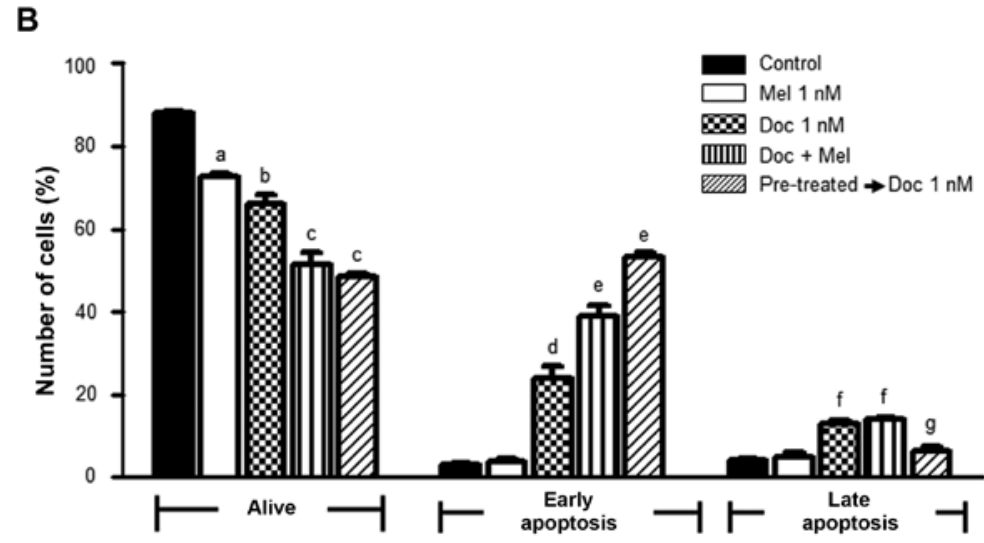

Figure 3. Potentiating effect of melatonin on the docetaxel-induced apoptosis of MCF-7 cells. MCF-7 cells were treated with docetaxel (1 nM), melatonin $(1 \mathrm{nM})$ or both for $24 \mathrm{~h}$. Melatonin pre-treatment consisted of incubation for $24 \mathrm{~h}$ with melatonin $(1 \mathrm{nM})$ prior to the addition of docetaxel. Apoptosis was evaluated by the Annexin V-PI binding assay. (A) Representative dot-plots showing viable/live cells (left bottom panel, Annexin V-/IP-), early apoptotic (right bottom panel, Annexin $\mathrm{V}^{+} / \mathrm{IP}^{-}$), late apoptotic (right top panel, Annexin $\mathrm{V}^{+} / \mathrm{IP}^{+}$) and necrotic (left top panel, Annexin $/ \mathrm{IP}^{+}$) cells. The number represents the percentage of cells in each condition. (B) Quantification of the number of cells in each population. Data are expressed as the means \pm SEM of 3 independent experiments; ${ }^{\mathrm{a}} \mathrm{p}<0.01 \mathrm{vs}$. control (live) cells; ${ }^{\mathrm{b}} \mathrm{p}<0.001 \mathrm{vs.} \mathrm{control} \mathrm{(live)} \mathrm{cells;}{ }^{\mathrm{c}} \mathrm{p}<0.001 \mathrm{vs}$. docetaxel alone-treated live cells; ${ }^{\mathrm{d}} \mathrm{p}<0.05 \mathrm{vs}$. control early apoptotic cells; ${ }^{\mathrm{e}} \mathrm{p}<0.05$ vs. docetaxel alone -treated early apoptotic cells; ${ }^{\mathrm{f}} \mathrm{p}<0.001 \mathrm{vs}$. control late apoptotic cells; ${ }^{\mathrm{g}} \mathrm{p}<0.001 \mathrm{vs}$. docetaxel alone-treated late apoptotic cells. Doc, docetaxel; Mel, melatonin.

necrotic cells. The effects of melatonin pre-treatment for $24 \mathrm{~h}$ were also examined. The results of Annexin V-FITC assay are shown in Fig. 3A and the quantification of the results obtained are shown in Fig. 3B. Following treatment with melatonin alone, we observed a slight decrease in the percentage of live cells compared to the control cells. Similarly, treatment with docetaxel $(1 \mathrm{nM})$ resulted in a decrease in the number of viable cells parallel to an increase in the percentage of cells undergoing early apoptosis. Of note, when the cells were simultaneously treated with docetaxel and melatonin, the number of viable cells was further decreased and the number of cells undergoing early apoptosis was augmented, suggesting that melatonin enhanced the apoptotic effects of docetaxel. Melatonin pre-treatment seemed to sensitize the MCF-7 cells to this chemotherapeutic agent, significantly further increasing the number of cells undergoing early apoptosis.

Effects of docetaxel and melatonin on gene expression. The changes in gene expression induced by chemotherapeutic agents employed at clinical doses remain largely unknown. In this study, we employed the human breast cancer $\mathrm{RT}^{2}$ Profiler PCR Array, to determine the changes induced by docetaxel $(1 \mu \mathrm{M})$ either alone or in combination with melatonin $(1 \mathrm{nM})$ on the gene expression profiles in MCF-7 cells. The RT ${ }^{2}$ Profiler PCR Array allows the simultaneous analysis of 84 genes relevant to a specific pathway or disease state and includes genes involved in one or more processeses, such as angiogenesis, adhesion, proteolysis, cell cycle progression and apoptosis. Melatonin alone significantly enhanced the expression of some genes, such as TP53, cyclin-dependent kinase inhibitor 1A (CDKN1A), cadherin $13(C D H 13)$ or $P G R$, whereas it diminished the expression of other genes, such as $c-M Y C$, interleukin (IL-6) or BCL-2 (data not shown). Establishing as criteria a change of at least 1.5 -fold either with docetaxel alone or in combination with melatonin (in comparison with expression of the untreated cells), we found that treatment with docetaxel upregulated the expression of 8 genes and downregulated the expression of 36 genes. When docetaxel was used 
Table II. List of the genes induced or repressed at least 1.5-fold in MCF-7 cells treated either with docetaxel $(1 \mu \mathrm{M})$ or docetaxel $(1 \mu \mathrm{M})+$ melatonin $(1 \mathrm{nM})$ for $6 \mathrm{~h}$.

\begin{tabular}{|c|c|c|c|}
\hline Docetaxel & $\begin{array}{l}\text { Fold } \\
\text { regulation }\end{array}$ & $\begin{array}{c}\text { Docetaxel + } \\
\text { melatonin }\end{array}$ & $\begin{array}{l}\text { Fold } \\
\text { regulation }\end{array}$ \\
\hline GSTP1 & -7.31 & GSTP1 & -10.10 \\
\hline$P G R$ & -6.50 & BIRC5 & -7.36 \\
\hline KRT8 & -4.08 & $T P 73$ & -5.66 \\
\hline$T P 73$ & -3.97 & $P G R$ & -4.89 \\
\hline CST6 & -3.71 & CST6 & -3.94 \\
\hline $\mathrm{HICl}$ & -3.43 & $S F N$ & -3.76 \\
\hline$M A P K 1$ & -2.96 & TWIST1 & -2.97 \\
\hline PTGS2 & -2.85 & $N R 3 C 1$ & -2.77 \\
\hline$N R 3 C 1$ & -2.75 & $M U C 1$ & -2.61 \\
\hline TP53 & -2.69 & THBS1 & -2.53 \\
\hline$B R C A 1$ & -2.60 & NME1 & -2.48 \\
\hline GRB7 & -2.51 & $B R C A 1$ & -2.46 \\
\hline$J U N$ & -2.45 & PTGS2 & -2.46 \\
\hline$S R C$ & -2.28 & MKI67 & -2.41 \\
\hline$C D K 2$ & -2.23 & $R B 1$ & -2.33 \\
\hline$S F N$ & -2.23 & GATA3 & -2.28 \\
\hline TWIST1 & -2.22 & SERPINE1 & -2.15 \\
\hline THBS1 & -2.17 & $K R T 8$ & -2.08 \\
\hline FOXAI & -2.14 & $M Y C$ & -2.06 \\
\hline$V E G F A$ & -1.96 & KRT18 & -2.03 \\
\hline$R B 1$ & -1.95 & $M A P K 1$ & -1.96 \\
\hline$N M E 1$ & -1.87 & IL6 & -1.95 \\
\hline$T G F B 1$ & -1.87 & $J U N$ & -1.82 \\
\hline$C D K N 1 C$ & -1.84 & $A B C B 1$ & -1.79 \\
\hline$R A R B$ & -1.83 & KRT19 & -1.79 \\
\hline SLIT2 & -1.80 & $V E G F A$ & -1.75 \\
\hline RASSF 1 & -1.79 & $A K T 1$ & -1.74 \\
\hline$C D K N 1 A$ & -1.75 & $B C L-2$ & -1.65 \\
\hline$C T N N B 1$ & -1.70 & $B R C A 2$ & -1.52 \\
\hline CDH13 & -1.69 & $I G F I R$ & 1.55 \\
\hline$C D K N 2 A$ & -1.69 & CCNAI & 1.60 \\
\hline CSF1 & -1.68 & TP53 & 1.86 \\
\hline KRT5 & -1.67 & $I D 1$ & 1.88 \\
\hline$S F R P 1$ & -1.65 & $C C N D 1$ & 1.95 \\
\hline$X B P 1$ & -1.61 & $A T M$ & 2.04 \\
\hline KRT18 & -1.54 & $I G F B P 3$ & 2.14 \\
\hline ESR2 & 1.69 & $C D K N 1 A$ & 2.17 \\
\hline IDI & 1.71 & $A P C$ & 2.55 \\
\hline SNAI2 & 1.77 & $E G F$ & 2.71 \\
\hline GATA3 & 1.91 & $B A D$ & 2.83 \\
\hline$M U C 1$ & 1.92 & $C C N D 2$ & 3.29 \\
\hline GLII & 2.00 & CDH13 & 5.35 \\
\hline$M Y C$ & 2.17 & SNAI2 & 5.86 \\
\hline CCNAI & 2.43 & $I G F 1$ & 8.86 \\
\hline
\end{tabular}

in combination with melatonin, we observed the upregulation of 15 genes and the downregulation of 29 genes (Table II). TP53, BAD and CDKN1A were upregulated $>3$-fold and mucin
1 (MUC1), BCL-2 and $c-M Y C$ were downregulated $>3$-fold (Fig. 4A). The following genes were selected for further analysis by specific RT-qPCR: TP53 and $C D K N 1 A$ as cell cycle regulators, and $B A D$ and $B C L-2$ as genes involved in apoptosis. Docetaxel $(1 \mu \mathrm{M})$ significantly inhibited the expression of TP53 and CDKN1A (Fig. 4B), and treatment with melatonin $(1 \mathrm{nM})$ counteracted this inhibitory effect. The expression of the pro-apoptotic gene $B A D$ was stimulated by docetaxel and co-treatment with melatonin further increased its expression, whereas the expression of the anti-apoptotic $B C L-2$ gene was significantly decreased. Treatment with melatonin enhanced this inhibitory effect (Fig. 4C). We analyzed the expression of $B A X$, another pro-apoptotic member of the family; similar to $B A D, B A X$ expression was stimulated by docetaxel and melatonin enhanced this stimulatory effect (Fig. 4C).

Among the genes classified as transcription factors or involved in angiogenesis and/or cell adhesion, $M U C 1$, GATA binding protein 3 (GATA3) and $c-M Y C$ were downregulated (>3-fold), and TP53 and CDH13 were upregulated (>4-fold) when the cells were treated simultaneously with melatonin and docetaxel in comparison with the cells treated only with the taxane (Fig. 5A). Specific RT-PCR analyses confirmed that docetaxel $(1 \mu \mathrm{M})$ stimulated the expression of the transcription factors, MUC1, GATA3 and $c-M Y C$, whereas a physiological concentration of melatonin counteracted this stimulatory effect of the chemotherapeutic agent (Fig. 5B). The expression of $\mathrm{CDH} 13$ (involved in angiogenesis) was inhibited by docetaxel and melatonin reversed this effect (Fig. 5C).

\section{Discussion}

In patients diagnosed with locally advanced breast cancer and a positive estrogen receptor status, chemotherapy is often recommended when cancer spreads outside the breast and axillary area. Several chemotherapy protocols for breast cancer include docetaxel, a mitotic inhibitor acting as a spindle poison (39).

Apart from undesirable side-effects, the molecular changes induced by chemotherapy in cancer cells remain largely unknown. The identification of such alterations may contribute to an improved efficacy and may help to elucidate the mechanisms responsible for undesirable processes, such as drug resistance. Gene expression and post-translational modification profiles have recently been obtained in all types of tumors and cancer cell lines treated with chemotherapeutic drugs $(25,40)$.

Melatonin has oncostatic actions, counteracting the estrogen-mediated activation and modulating the expression and activity of enzymes involved in the synthesis of estrogens (2,6,41-43). Melatonin treatment sensitizes MCF-7 cells to radiation, decreasing cell proliferation, increasing the proportion of cells in the $\mathrm{G}_{0}-\mathrm{G}_{1}$ phase of the cell cycle and downregulating the expression of proteins implicated in double-strand DNA break repair (12). Melatonin regulates global gene expression in human breast cancer cells (36). However, the molecular mechanisms through which melatonin modulates changes in gene expression, cell proliferation and cell cycle progression triggered by chemotherapeutic drugs in estrogen-responsive breast tumors remain largely unknown. 


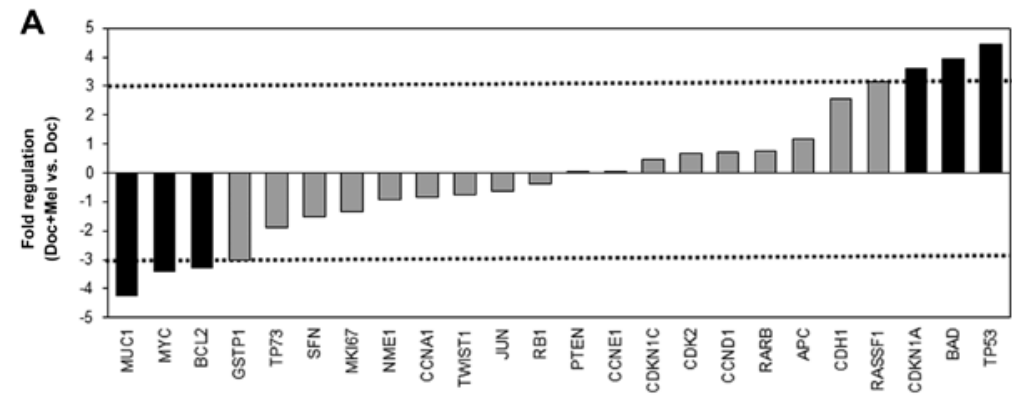

B
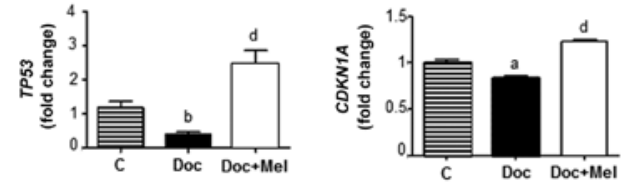

C
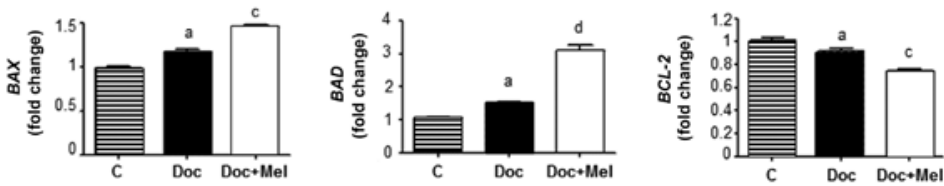

Figure 4. Comparison of the changes in fold regulation of genes involved in apoptosis and cell cycle in MCF-7 cells treated with docetaxel or docetaxel + melatonin. (A) PCR data from the RT ${ }^{2}$ PCR Array. MCF-7 cells were treated for $6 \mathrm{~h}$ with docetaxel $(1 \mu \mathrm{M})$ alone or in combination with melatonin (1 nM) and total RNA was isolated from the cells and reverse transcribed. The cDNA were used to perform the RT ${ }^{2}$ PCR Array. Data are expressed as the (Doc + Mel)induced fold regulation relative to docetaxel treatment alone. Genes that showed a $>3$-fold difference in expression (black bars) were selected for validation by specific RT-qPCR. (B) RT-qPCR analysis of the cell cycle-related genes, TP53 and $C D K N 1 A$. (C) RT-qPCR analysis of the apoptosis-related genes, $B A X, B A D$ and $B C L-2$. All data are expressed as fold changes relative to the control cells (means \pm SEM) from 3 independent experiments; ${ }^{\mathrm{a}} \mathrm{p}<0.05 \mathrm{vs}$. control; ${ }^{\mathrm{b}} \mathrm{p}<0.001$ vs. control; ${ }^{\mathrm{p}} \mathrm{p}<0.01$ vs. docetaxel; ${ }^{\mathrm{d}} \mathrm{p}<0.001$ vs. docetaxel. Doc, docetaxel; Mel, melatonin.

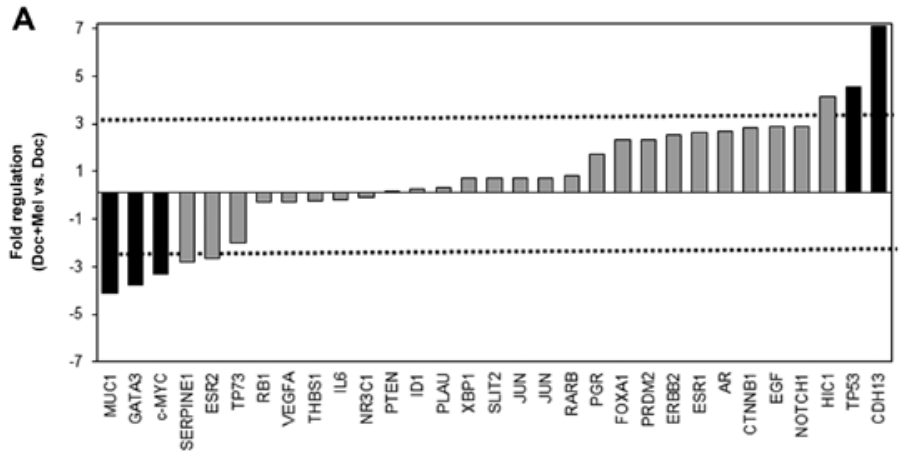

B
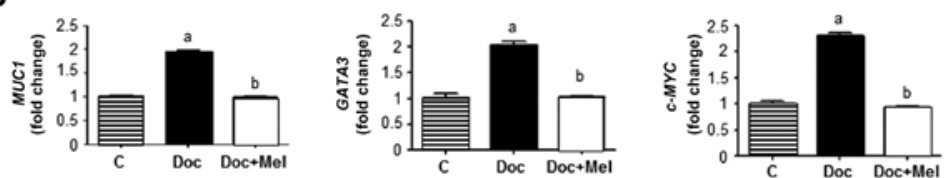

C

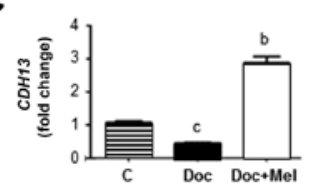

Figure 5. Comparison of the changes in fold regulation of genes encoding transcription factors and angiogenesis in MCF-7 cells. (A) PCR array data. MCF-7 cells were treated for $6 \mathrm{~h}$ with docetaxel $(1 \mu \mathrm{M})$, alone or in combination with melatonin $(1 \mathrm{nM})$ and total RNA was isolated from the cells and reverse transcribed. cDNA were used to perform the RT ${ }^{2}$ PCR array. Data are expressed as the (Doc + Mel)-induced fold regulation relative to docetaxel treatment alone. Genes that showed a $>3$-fold difference in expression (black bars) were selected for validation by specific RT-qPCR. (B) RT-qPCR analysis of the mRNA expression levels of the transcription factors, $M U C 1$, GATA3 and $c-M Y C$. (C) RT-qPCR analysis of the mRNA expression levels of the cell adhesion molecule, $C D$ H13. Data are expressed as fold changes relative to the control cells (means \pm SEM) from 3 independent experiments; ${ }^{\mathrm{a}} \mathrm{p}<0.001 \mathrm{vs}$. control; ${ }^{\mathrm{b}} \mathrm{p}<0.001 \mathrm{vs}$. docetaxel; ${ }^{\mathrm{p}} \mathrm{p}<0.01$ vs. control. Doc, docetaxel; Mel, melatonin. 
Therefore, in the present study, we examined the effects of the combination of docetaxel and melatonin using MCF-7 cells as a model.

Since MCF-7 cells are very sensitive to concentrations of docetaxel in the range of those used in chemotherapy protocols, we decided to test low concentrations of the taxane $(1 \mathrm{nM}$ and $0.1 \mathrm{nM}$ ) to examine the effects of melatonin combined with the chemotherapeutic agent on cell proliferation. Our results strongly suggested that the combination of melatonin and low doses of docetaxel resulted in the cooperative enhancement of cytotoxicity. Of note, treatment of the cells with melatonin prior to docetaxel treatment resulted in a higher inhibition of cell proliferation. These results point to melatonin as an enhancer of the anti-proliferative effects of docetaxel when the taxane is administered at lower doses than those administered to cancer patients.

We then analysed the changes that melatonin and docetaxel cause on the cell cycle. As previously reported (44), melatonin induces cell cycle arrest in the $G_{1}$ phase. Low concentrations of docetaxel induced a higher proportion of cells in the sub $\mathrm{G}_{0}-\mathrm{G}_{1}$ phase and of note, co-treatment with melatonin significantly increased the number of cells in the sub $G_{0}-G_{1}$ phase, indicating that melatonin potentiated the effects of docetaxel. Low concentrations of docetaxel decreased the number of viable/live cells and increased the percentage of cells undergoing early apoptosis. Melatonin enhanced this effect, more potently when added prior to treatment with the taxane. Our results are in agreement with those of a recent study reporting that melatonin induced cell inhibition and the apoptosis of MCF-7 cells through an increase in p53 acetylation and the inhibition of Akt/PI3K, modulating the MDM2/MDMX/ p300 pathway (45). Finally, we examine the expression of the apoptosis-related genes, $B A D, B A X$ and $B C L-2$, and found that melatonin potentiated the stimulatory effects of docetaxel on the expression of $B A D$, and provoked a strong inhibition of the expression of $B C L-2$. Thus, physiological concentrations of melatonin potentiated the cytotoxic effects of low concentrations of docetaxel, which may allow the therapeutic concentrations of anticancer drugs to be reduced.

In breast cancer patients, docetaxel is administered in doses oscillating from $75-200 \mathrm{mg} / \mathrm{m}^{2}$ every 3 weeks, roughly equivalent to concentrations of $1 \mu \mathrm{M}$ in breast cancer cells in culture medium. For this reason, we then examined the changes in gene expression profiles when the MCF-7 cells were treated with docetaxel $(1 \mu \mathrm{M})$, and found that 8 genes were upregulated and 36 were downregulated by at least 1.5 -fold. When docetaxel and melatonin were simultaneously added to the culture medium, 15 genes were upregulated and 29 downregulated by at least 1.5 -fold. We further analyzed the expression of 9 genes involved in cell cycle progression (TP53 and CDKN1A) angiogenesis $(C D H 13)$, apoptosis $(B A X$, $B A D$ and $B C L-2$ ), and gene transcription (GATA3, MUC1 and $c-M Y C)$. The genome guardian p53 maintains genome stability (46), and the expression of p53 and p21WAF1 is reduced in locally advanced breast cancer patients receiving neoadjuvant docetaxel plus epirubicin (47). The induction of p53 and p21WAF1 by melatonin has been suggested as part of the mechanism through which melatonin inhibits the proliferation of breast cancer cells (48). In the present study, docetaxel decreased the expression of TP53, CDKNIA, two key regulators of cell cycle. An intact $\mathrm{p} 53$ predicts sensitivity to breast cancer therapy and higher levels of p21 indicate a more indolent type of breast cancer (49). In our hands, docetaxel also decreased the expression of $\mathrm{CDH13}$, the loss of which has been shown to be associated with tumor malignancy, invasiveness and metastasis (50). Of note, melatonin counteracted the negative effect of docetaxel, increasing the expression of these 3 genes, considered as tumor suppressors with a key role in cell cycle control and tumor progression.

BAX and BAD are pro-apoptotic and BCL-2 is an antiapoptotic factor classified as an oncogene (51). BAD neutralizes anti-apoptotic BCL-2 members, which in turn, modulate the intrinsic apoptotic pathway by binding and neutralizing other proteins that act as mitochondrial permeabilizers, such as the pro-apoptotic protein, BAX (52). $B A X$ expression is upregulated by $\mathrm{p} 53$ and $\mathrm{BAX}$ is involved in p53-mediated apoptosis. $B A D$ (BCL-2-associated death promoter) is a pro-apoptotic member of the $B C L-2$ gene family involved in the initiation of apoptosis. BAD forms heterodimers with anti-apoptotic proteins (such as BCL-2) inactivating them, allowing for BAX-triggered apoptosis (51). Docetaxel has been reported to both stimulate and inhibit the apoptosis of human melanoma (53), whereas in MCF-7 cells, nanomolar concentrations of docetaxel have been shown to induce apoptosis likely through the phosphorylation of BCL-2 (54). In this study, we found that treatment with docetaxel $(1 \mu \mathrm{M})$ significantly increased the expression of $B A X$ and $B A D$, and decreased the levels of $B C L-2$. Importantly, melatonin potentiated the stimulatory effects of docetaxel on the expression of the pro-apoptotic genes, $B A X$ and $B A D$, and further inhibited the expression of the anti-apoptotic gene, $B C L-2$. Our results strongly suggest that melatonin potentiates the pro-apoptotic effects of docetaxel in breast cancer cells by modulating the expression of the $B A X, B A D$ and $B C L-2$ genes.

GATA3 is a transcription factor differentially expressed in breast cancer (55). GATA3 mediates the transcriptional upregulation of $M U C 1$ (56). MUC1 expression has been found in plasma cells of patients with lymph node metastasis or micrometastasis (57). $c-M Y C$ is a classical oncogene that is mutated, translocated or overexpressed in many types of tumors and is upregulated by estradiol in MCF-7 cells, whereas melatonin abolishes this effect almost completely (58). Melatonin, in combination with arsenic trioxide, has been shown to stimulate apoptosis by increasing p53 protein levels, increasing the ratio of BAX/BCL-2 and suppressing survivin-mediated $c-M Y C$ and $h T E R T$ expression (44). In this study, we found that docetaxel induced the expression of GATA3, MUC1 and $c-M Y C$, whereas melatonin counteracted the stimulatory effects of this chemotherapeutic agent. Again, melatonin seemed to exert a protective effect, since the inhibition of the expression of $M U C 1, G A T A 3$ and the proto-oncogene, $c-M Y C$, may well correlate with both lower levels of the expression of factors involved in cellular growth and a less aggressive invasion phenotype.

In conclusion, our results point once more to melatonin as a useful molecule with a potential to be considered as an adjuvant in breast cancer therapy. Since the nocturnal increase in plasma melatonin is much lower in patients with estrogen-positive breast cancer than in healthy women (59), the administration of melatonin at physiological doses may compensate this deficit of 
melatonin in these patients. We report herein that the concomitant use of melatonin and docetaxel sensitizes human breast cancer cells to the chemotherapeutic agent. When docetaxel is used at low concentrations, combinations of melatonin plus docetaxel have a synergistic effect in arresting cell proliferation and inducing the apoptosis in MCF-7 cells. Melatonin also modulates changes in gene expression induced by docetaxel at higher concentrations (equivalent to the docetaxel dose in chemotherapy protocols). Our results suggest that patients receiving docetaxel as part of their chemotherapy treatment may benefit in the next future with a co-treatment with melatonin as an adjuvant agent, allowing for a reduction in the dose of the chemotherapeutic agent administered, which may result in better tolerance and less adverse effects. The efficacy of melatonin when administered together with chemotherapy has been tested in several trials; however, to date, at least to the best of our knowledge, it has never been tested in combination with docetaxel. Our results indicate that it may be worthy to perform randomized, double blind, placebo-controlled trials in the near future in breast cancer patients to clarify the efficacy of this association.

\section{Acknowledgements}

The present study was supported by grants from the Spanish Science Technology and Innovation Ministry (grant no. SAF2016-77103-P) and the Research Institute Valdecilla (grant no. APG/12).

\section{References}

1. Cos S, Martínez-Campa C, Mediavilla MD and SánchezBarceló EJ: Melatonin modulates aromatase activity in MCF-7 human breast cancer cells. J Pineal Res 38: 136-142, 2005.

2. Cos S, González A, Martínez-Campa C, Mediavilla MD, AlonsoGonzález C and Sánchez-Barceló EJ: Melatonin as a selective estrogen enzyme modulator. Curr Cancer Drug Targets 8: 691-702, 2008 .

3. Cos S,GonzálezA,Güezmes A,MediavillaMD,Martínez-CampaC, Alonso-González C and Sánchez-Barceló EJ: Melatonin inhibits the growth of DMBA-induced mammary tumors by decreasing the local biosynthesis of estrogens through the modulation of aromatase activity. Int J Cancer 118: 274-278, 2006.

4. Rato AG, Pedrero JG, Martínez MA, del Río B, Lazo PS and Ramos S: Melatonin blocks the activation of estrogen receptor for DNA binding. FASEB J 13: 857-868, 1999.

5. Bouhoute A and Leclercq G: Calmodulin decreases the estrogen binding capacity of the estrogen receptor. Biochem Biophys Res Commun 227: 651-657, 1996.

6. del Río B, García Pedrero JM, Martínez-Campa C,Zuazua P,Lazo PS and Ramos S: Melatonin, an endogenous-specific inhibitor of estrogen receptor alpha via calmodulin. J Biol Chem 279 : 38294-38302, 2004.

7. Aronica SM, Kraus WL and Katzenellenbogen BS: Estrogen action via the cAMP signaling pathway: Stimulation of adenylate cyclase and cAMP-regulated gene transcription. Proc Natl Acad Sci USA 91: 8517-8521, 1994.

8. Godson Cand Reppert SM:The Mella melatonin receptor is coupled to parallel signal transduction pathways. Endocrinology 138: 397-404, 1997.

9. Cos S and Blask DE: Melatonin modulates growth factor activity in MCF-7 human breast cancer cells. J Pineal Res 17: 25-32, 1994.

10. Molis TM, Spriggs LL, Jupiter Y and Hill SM: Melatonin modulation of estrogen-regulated proteins, growth factors, and proto-oncogenes in human breast cancer. J Pineal Res 18: 93-103, 1995.

11. Cos S, Blask DE, Lemus-Wilson A and Hill AB: Effects of melatonin on the cell cycle kinetics and 'estrogen-rescue' of MCF-7 human breast cancer cells in culture. J Pineal Res 10: 36-42, 1991.
12. Alonso-González C, González A, Martínez-Campa C, MenéndezMenéndez J, Gómez-Arozamena J, García-Vidal A and Cos S: Melatonin enhancement of the radiosensitivity of human breast cancer cells is associated with the modulation of proteins involved in estrogen biosynthesis. Cancer Lett 370: 145-152, 2016.

13. Leon-Blanco MM, Guerrero JM, Reiter RJ, Calvo JR and Pozo D: Melatonin inhibits telomerase activity in the MCF-7 tumor cell line both in vivo and in vitro. J Pineal Res 35: 204-211, 2003.

14. Martínez-Campa CM, Alonso-González C, Mediavilla MD, Cos S, González A and Sánchez-Barceló EJ: Melatonin downregulates hTERT expression induced by either natural estrogens (17beta-estradiol) or metalloestrogens (cadmium) in MCF-7 human breast cancer cells. Cancer Lett 268: 272-277, 2008.

15. Cos S, Fernández R, Güézmes A and Sánchez-Barceló EJ: Influence of melatonin on invasive and metastatic properties of MCF-7 human breast cancer cells. Cancer Res 58: 4383-4390, 1998.

16. González A, Alvarez-García V, Martínez-Campa C, AlonsoGonzález $\mathrm{C}$ and Cos S: Melatonin promotes differentiation of 3T3-L1 fibroblasts. J Pineal Res 52: 12-20, 2012.

17. Alvarez-García V, González A, Alonso-González C, Martínez-Campa C and Cos S: Melatonin interferes in the desmoplastic reaction in breast cancer by regulating cytokine production. J Pineal Res 52: 282-290, 2012.

18. Alvarez-García V, González A, Martínez-Campa C, AlonsoGonzález C and Cos S: Melatonin modulates aromatase activity and expression in endothelial cells. Oncol Rep 29: 2058-2064, 2013.

19. Lissoni P, Barni S, Mandalà M, Ardizzoia A, Paolorossi F, Vaghi M, Longarini R, Malugani F and Tancini G: Decreased toxicity and increased efficacy of cancer chemotherapy using the pineal hormone melatonin in metastatic solid tumour patients with poor clinical status. Eur J Cancer 35: 1688-1692, 1999.

20. Lissoni P, Chilelli M, Villa S, Cerizza L and Tancini G: Five years survival in metastatic non-small cell lung cancer patients treated with chemotherapy alone or chemotherapy and melatonin: A randomized trial. J Pineal Res 35: 12-15, 2003.

21. Sookprasert A, Johns NP, Phunmanee A, Pongthai P, Cheawchanwattana A, Johns J, Konsil J, Plaimee P, Porasuphatana $\mathrm{S}$ and Jitpimolmard S: Melatonin in patients with cancer receiving chemotherapy: A randomized, double-blind, placebo-controlled trial. Anticancer Res 34: 7327-7337, 2014.

22. Seely D, Wu P, Fritz H, Kennedy DA, Tsui T, Seely AJ and Mills E: Melatonin as adjuvant cancer care with and without chemotherapy: A systematic review and meta-analysis of randomized trials. Integr Cancer Ther 11: 293-303, 2012.

23. Wang YM, Jin BZ, Ai F, Duan CH, Lu YZ, Dong TF and Fu QL: The efficacy and safety of melatonin in concurrent chemotherapy or radiotherapy for solid tumors: A meta-analysis of randomized controlled trials. Cancer Chemother Pharmacol 69: 1213-1220, 2012.

24. Reiter RJ, Rosales-Corral SA, Tan DX, Acuña-Castroviejo D, Qin L, Yang SF and Xu K: Melatonin, a full service anti-cancer agent: Inhibition of initiation, progression and metastasis. Int $\mathrm{J}$ Mol Sci 18: E843, 2017.

25. Martínez-Campa C, Menéndez-Menéndez J, Alonso-González C, González A, Álvarez-García V and Cos S: What is known about melatonin, chemotherapy and altered gene expression in breast cancer (Review). Oncol Lett 13: 2003-2014, 2017.

26. Xiang S, Dauchy RT, Hauch A, Mao L, Yuan L, Wren MA, Belancio VP, Mondal D, Frasch T, Blask DE, et al: Doxorubicin resistance in breast cancer is driven by light at night-induced disruption of the circadian melatonin signal. J Pineal Res 59: 60-69, 2015.

27. Granzotto M, Rapozzi V, Decorti G and Giraldi T: Effects of melatonin on doxorubicin cytotoxicity in sensitive and pleiotropically resistant tumor cells. J Pineal Res 31: 206-213, 2001.

28. Woo SM, Min KJ and Kwon TK: Melatonin-mediated Bim up-regulation and cyclooxygenase-2 (COX-2) down-regulation enhances tunicamycin-induced apoptosis in MDA-MB-231 cells. J Pineal Res 58: 310-320, 2015.

29. Yun M, Kim EO, Lee D, Kim JH, Kim J, Lee H, Lee J and Kim SH: Melatonin sensitizes H1975 non-small-cell lung cancer cells harboring a T790M-targeted epidermal growth factor receptor mutation to the tyrosine kinase inhibitor gefitinib. Cell Physiol Biochem 34: 865-872, 2014.

30. Plaimee P, Weerapreeyakul N, Barusrux S and Johns NP: Melatonin potentiates cisplatin-induced apoptosis and cell cycle arrest in human lung adenocarcinoma cells. Cell Prolif 48: 67-77, 2015. 
31. Pariente R, Pariente JA, Rodríguez AB and Espino J: Melatonin sensitizes human cervical cancer HeLa cells to cisplatin-induced cytotoxicity and apoptosis: Effects on oxidative stress and DNA fragmentation. J Pineal Res 60: 55-64, 2016.

32. Uguz AC, Cig B, Espino J, Bejarano I, Naziroglu M, Rodríguez AB and Pariente JA: Melatonin potentiates chemotherapy-induced cytotoxicity and apoptosis in rat pancreatic tumor cells. J Pineal Res 53: 91-98, 2012.

33. Ma C, Li LX, Zhang Y, Xiang C, Ma T, Ma ZQ and Zhang ZP: Protective and sensitive effects of melatonin combined with adriamycin on $\mathrm{ER}^{+}$(estrogen receptor) breast cancer. Eur J Gynaecol Oncol 36: 197-202, 2015

34. Koşar PA, Nazıroğlu M, Övey IS and Çĭ̆ B: Synergic effects of doxorubicin and melatonin on apoptosis and mitochondrial oxidative stress in MCF-7 breast cancer cells: Involvement of TRPV1 channels. J Membr Biol 249: 129-140, 2016.

35. Rodríguez-García A, Mayo JC, Hevia D, Quirós-González I, Navarro M and Sainz RM: Phenotypic changes caused by melatonin increased sensitivity of prostate cancer cells to cytokine-induced apoptosis. J Pineal Res 54: 33-45, 2013.

36. Lee SE, Kim SJ, Youn JP, Hwang SY, Park CS and Park YS: MicroRNA and gene expression analysis of melatonin-exposed human breast cancer cell lines indicating involvement of the anticancer effect. J Pineal Res 51: 345-352, 2011.

37. Mosmann T: Rapid colorimetric assay for cellular growth and survival: Application to proliferation and cytotoxicity assays. J Immunol Methods 65: 55-63, 1983.

38. Livak KJ and Schmittgen TD: Analysis of relative gene expression data using real-time quantitative PCR and the 2(-Delta Delta C(T)) Method. Methods 25: 402-408, 2001.

39. Iwao-Koizumi K, Matoba R, Ueno N, Kim SJ, Ando A, Miyoshi Y, Maeda E, Noguchi S and Kato K: Prediction of docetaxel response in human breast cancer by gene expression profiling. J Clin Oncol 23: 422-431, 2005.

40. Lumachi F, Chiara GB, Foltran L and Basso SM: Proteomics as a guide for personalized adjuvant chemotherapy in patients with early breast cancer. Cancer Genomics Proteomics 12: 385-390, 2015.

41. Kiefer T, Ram PT, Yuan L and Hill SM: Melatonin inhibits estrogen receptor transactivation and cAMP levels in breas cancer cells. Breast Cancer Res Treat 71: 37-45, 2002.

42. González A, Cos S, Martínez-Campa C, Alonso-González C, Sánchez-Mateos S, Mediavilla MD and Sánchez-Barcelo EJ: Selective estrogen enzyme modulator actions of melatonin in human breast cancer cells. J Pineal Res 45: 86-92, 2008.

43. Vriend $\mathbf{J}$ and Reiter RJ: Breast cancer cells: Modulation by melatonin and the ubiquitin-proteasome system - a review. Mol Cell Endocrinol 417: 1-9, 2015.

44. Nooshinfar E, Bashash D, Safaroghli-Azar A, Bayati S, RezaeiTavirani M, Ghaffari SH and Akbari ME: Melatonin promotes ATO-induced apoptosis in MCF-7 cells: Proposing novel therapeutic potential for breast cancer. Biomed Pharmacother 83 : 456-465, 2016.

45. Proietti S, Cucina A, Dobrowolny G, D'Anselmi F, Dinicola S, Masiello MG, Pasqualato A, Palombo A, Morini V, Reiter RJ et al: Melatonin down-regulates MDM2 gene expression and enhances p53 acetylation in MCF-7 cells. J Pineal Res 57: $120-129,2014$.
46. Berger C, Qian Y and Chen X: The p53-estrogen receptor loop in cancer. Curr Mol Med 13: 1229-1240, 2013.

47. Tiezzi DG, Andrade JM, Ribeiro-Silva A, Zola FE, Marana HR and Tiezzi MG: HER-2, p53, p21 and hormonal receptors proteins expression as predictive factors of response and prognosis in locally advanced breast cancer treated with neoadjuvant docetaxel plus epirubicin combination. BMC Cancer 7: 36-46, 2007.

48. Mediavilla MD, Cos S and Sánchez-Barceló EJ: Melatonin increases p53 and p21WAF1 expression in MCF-7 human breast cancer cells in vitro. Life Sci 65: 415-420, 1999.

49. Elledge RM and Allred DC: Prognostic and predictive value of p53 and p21 in breast cancer. Breast Cancer Res Treat 52: 79-98, 1998.

50. Moelans CB, Verschuur-Maes AH and van Diest PJ: Frequent promoter hypermethylation of BRCA2, CDH13, MSH6, PAX5, PAX6 and WT1 in ductal carcinoma in situ and invasive breast cancer. J Pathol 225: 222-231, 2011.

51. Tudor G, Aguilera A, Halverson DO, Laing ND and Sausville EA Susceptibility to drug-induced apoptosis correlates with differential modulation of $\mathrm{Bad}, \mathrm{Bcl}-2$ and $\mathrm{Bcl}-\mathrm{xL}$ protein levels. Cell Death Differ 7: 574-586, 2000.

52. Correia C, Lee SH, Meng XW, Vincelette ND, Knorr KL, Ding H, Nowakowski GS, Dai H and Kaufmann SH: Emerging understanding of Bcl-2 biology: Implications for neoplastic progression and treatment. Biochim Biophys Acta 1853: 1658-1671, 2015.

53. Mhaidat NM, Zhang XD, Jiang CC and Hersey P: Docetaxelinduced apoptosis of human melanoma is mediated by activation of c-Jun NH2-terminal kinase and inhibited by the mitogenactivated protein kinase extracellular signal-regulated kinase 1/2 pathway. Clin Cancer Res 13: 1308-1314, 2007.

54. Berchem GJ, Bosseler M, Mine N and Avalosse B: Nanomolar range docetaxel treatment sensitizes MCF-7 cells to chemotherapy induced apoptosis, induces G2M arrest and phosphorylates bcl-2. Anticancer Res 19A: 535-540, 1999.

55. Zang H, Li N, Pan Y and Hao J: Identification of upstream transcription factors (TFs) for expression signature genes in breast cancer. Gynecol Endocrinol 33: 193-198, 2017.

56. Abba MC, Nunez MI, Colussi AG, Croce MV, Segal-Eiras A and Aldaz CM: GATA3 protein as a MUC1 transcriptional regulator in breast cancer cells. Breast Cancer Res 8: R64, 2006.

57. Puttipanyalears C, Kitkumthorn N, Buranapraditkun S, Keelawat $\mathrm{S}$ and Mutirangura $\mathrm{A}$ : Breast cancer upregulating genes in stromal cells by LINE-1 hypermethylation and micrometastatic detection. Epigenomics 8: 475-486, 2016.

58. Girgert R, Hanf V, Emons $G$ and Gründker C: Membrane-bound melatonin receptor MT1 down-regulates estrogen responsive genes in breast cancer cells. J Pineal Res 47: 23-31, 2009.

59. Tamarkin L, Danforth D, Lichter A, DeMoss E, Cohen M, Chabner B and Lippman M: Decreased nocturnal plasma melatonin peak in patients with estrogen receptor positive breast cancer. Science 216: 1003-1005, 1982. 